\title{
Heidegger e a sofística nossa de cada dia
}

\author{
FELIPE RAMOS GALL *
}

* Doutorando em Filosofia pela PUC-Rio

Bolsista do Conselho Nacional de Desenvolvimento Científico e Tecnológico (CNPq) felipegall@outlook.com
RESUMO Desde os primórdios da filosofia, parece haver um embate entre ela e o senso comum. O senso comum escarnece da inutilidade da filosofia, ao passo que esta desdenha da banalidade daquele. Tendo isso em mente, nosso interesse aqui é analisar uma passagem proferida por Heidegger em sua preleção $A$ essência da verdade, em que ele afirma: "Mas neste mesmo instante da história do mundo que é preenchido pelo início da filosofia, começa também a dominação expressa do senso comum (da sofística)". Buscamos investigar em que sentido Heidegger parece fazer uma equivalência entre senso comum e sofística, e qual a sua relação com a filosofia. Partindo da lógica própria do senso comum, e com auxílio das valiosas intuições presentes na obra de Platão, procuramos mostrar a intrincada reciprocidade existente entre filosofia e sofística, pensamento e senso comum, assim como do porquê de vivermos em uma época de dominação expressa do senso comum, isto é, da sofística.

PALAVRAS-Chave Heidegger, Sofística, Cotidianidade, Filosofia.

ABSTRACT Since the beginnings of philosophy, there seems to be a clash between it and the common sense. The common sense mocks the uselessness of philosophy, whereas the philosophy disdain of the banality of the common sense. With that in mind, our interest here is to analyze a passage given by Heidegger in his lecture On the essence of truth, in which he asserts: "However, in the same period in which the beginning of philosophy takes place, the marked domination of common sense (sophistry) also begins". We seek to investigate in what sense Heidegger seems to make an equivalence between common sense and sophistry, and what is its relation to the philosophy. Starting from the common sense's own logic, and with the help of the valuable insights present in Plato's work, we try to show the intricate reciprocity between philosophy and sophistry, thought and common sense, as well as why we live in an era of the express domination of the common sense, that is, of the sophistry.

KEYWORDS Heidegger, Sophistry, Everydayness, Philosophy. 
JÁ desde a Antiguidade havia narrativas sobre o escárnio das pessoas comuns em relação a filosofia. Há, por exemplo, a famigerada anedota que nos conta do riso de uma escrava trácia ao ver que Tales de Mileto, andando distraído enquanto olhava para o céu, pois desejava conhecer os mistérios celestes, acabou caíndo em um buraco, pois se esqueceu de olhar para os próprios pés ${ }^{1}$. Dado que Tales é considerado o primeiro filósofo, não seria exagero afirmar que o desdém pela vida filosófica surgiu concomitantemente com a própria filosofia. Desde que há filosofia, há também o deboche do senso comum em relação a ela. Esse senso comum nada mais é que o "saudável entendimento humano" (der gesunde Menschenverstand) ${ }^{2}$, nosso "bom senso" que teima em se apegar àquilo que é imediatamente útil ou àquilo que se mostra valoroso, ou seja, àquelas coisas que "ninguém em sã consciência” seria capaz de rejeitar ou de preferir. Em sã consciência, todos queremos o que nos é útil. De fato. Mas há aqueles que dedicam suas vidas a algo que, a primeira vista, é completamente inútil: a filosofia. É ridículo ver alguém "jogando a vida fora”, desperdiçando o precioso e curto tempo que nos foi dado tratando de questões inúteis, dedicando a vida a algo que muito provavelmente não nos trará o menor prestígio, e muito menos “dará dinheiro”. Só pode ser loucura. Hegel assevera: “A filosofia, segundo a sua própria natureza, é algo de esotérico (...); para o senso comum, o mundo da filosofia é um mundo às avessas”3. Achamos graça dos loucos, da sua excentricidade, do seu caráter imprevisível, que sempre surpreende porque justamente escapa ao padrão. Mas esse riso tem por detrás um caráter de dó, de pena. Que pena que ele não é normal como a gente, que pena que ele passará a vida toda desse jeito. Platão, no Górgias, nos apresenta essa posição a partir de seu personagem Cálicles, que confronta Sócrates dizendo:

A filosofia, Sócrates, é de fato muito atraente para quem a estuda com moderação na mocidade, porém acaba por arruinar quem a ela se dedica mais tempo do que fora razoável. (...) De fato, não somente desconhecerá as leis da cidade,

1 Cf. PLATÃO, Teeteto, 174a, bem como DIÓGENES LAÉRCIO, Vidas e doutrinas dos filósofos ilustres, I, §34, p. 21.

2 Cf. HEIDEGGER, GA 6o, p. 36.

3 Apud BORNHEIM, Introdução ao filosofar, p. 62. 
como a linguagem que será preciso usar no trato público ou particular, bem como carecerá de experiência com relação (...) às paixões e ao caráter geral dos homens. Logo que procuram ocupar-se com seus próprios negócios ou com a política, tornam-se ridículos, como ridículos, a meu ver, também se tornam os políticos que se dispõem a tomar parte em vossas reuniões e vossas disputas ${ }^{4}$.

A filosofia teria seu valor na juventude, como uma erudição que ajudaria o jovem a ser melhor formado e, por conseguinte, possibilitaria a ele um maior destaque entre seus pares quando fosse exercer a carreira política. Haveria aí, nesse caso, um valor para a filosofia, pois ela seria útil. Mas bastaria o jovem tornar-se adulto e iniciar de fato a vida política, e ter de passar a se preocupar com as questões sérias envolvendo o destino de sua cidade, para que a filosofia já se mostrasse como inútil, pois seria como que uma brincadeira ou um saber vazio quando comparado ao que estava em jogo nessa situação. Insistir em se dedicar a filosofia mesmo depois de jovem é ridículo, só um idiota trocaria as questões relevantes da vida política pelas questões abstratas e inúteis da filosofia. Ou ainda: teimar em se dedicar à vida filosófica seria um ato de extrema vaidade, de um egoísmo arrogante, de gente que se acha melhor do que os outros. Temos o testemunho de Aristóteles de que "todas as outras ciências serão mais necessárias que esta [a filosofia primeira], mas nenhuma lhe será superior"5. O filósofo se dedica àquele saber que é superior a todos os demais, ele põe-se acima dos reles mortais, e por conta disso se vê no direito de impor-se como a medida, o critério. Novamente Cálicles diz a Sócrates: "Se é sério e for verdade tudo o que disseste, então a vida dos homens está completamente revirada, e nós agimos, ao que

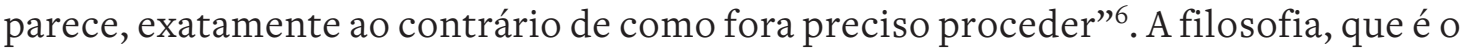
mundo cotidiano às avessas, propõe esse avesso como a regra, ela estabelece o certo e o errado. Ora, mas no fundo todos sabem o que é certo e errado, é uma questão de bom senso. Ninguém precisa estudar filosofia para julgar isso. Descartes inicia seu Discurso do método dizendo: “O bom senso é a coisa mais bem distribuída do mundo, pois cada um pensa estar tão bem provido dele, que mesmo aqueles mais difíceis de se satisfazerem com qualquer outra coisa não costumam desejar mais bom senso do que

4 PLATÃO, Górgias, 484c-e.

5 ARISTÓTELES, Metafísica, A 2, 983 a1os.

6 PLATÃO, Górgias, 481c. 
têm"7. Todos nós nos achamos providos de bom senso, e por conta disso tendemos a não questionar de fato as coisas, pois tudo se apresenta a nós como sendo óbvio. Daí surge o embate do senso comum com a filosofia: este incessante questionar da filosofia não é, além de inútil, vaidoso? Pois para quê precisamos ficar perguntando a causa de tudo a todo momento, se todos já mais ou menos sabem como viver as suas vidas de modo satisfatório?

Tendo isso em mente, nossa questão aqui gira ao redor de um comentário de Heidegger em sua preleção A essência da verdade, de 1930. Em dado momento, Heidegger diz: "Mas neste mesmo instante da história do mundo que é preenchido pelo início da filosofia, começa também a dominação expressa do senso comum (da sofística)" 8 . Nossa proposta é investigar em que sentido pôde Heidegger comparar o senso comum com a sofística, bem como o porquê de seu domínio se dar concomitantemente com o início da filosofia.

A questão diretriz que dirige todo o pensamento de Heidegger é a questão do ser. A pergunta pelo ser, contudo, já sempre pressupõe uma compreensão de ser como ponto de partida. A princípio, questionar o ser em seu sentido próprio não se refere ao homem. Qualquer desdobramento desse questionamento, no entanto, sempre remeterá a alguma compreensão de ser, e isso é próprio do homem. O homem é um ente, tal como a pedra, as plantas e os animais, de fato. Mas apenas o homem põe a pergunta pelo sentido de ser ${ }^{9}$. Ele é o sítio da questão do ser. E isso porque, seja lá de qual modo for, ele já sempre compreendeu ser. O homem, na medida em que é, compreende e já sempre compreendeu ser de alguma forma. O ser está enraizado no homem. Entendido desse modo, Heidegger expressa o ente que é compreensão de ser não como homem, mas como Dasein, ser-aí ${ }^{\circ}$. Querendo estabelecer a ontologia fundamental, isto é, pôr-se à altura da questão do sentido do ser em sua radicalidade, impôs-se como necessário uma analítica existencial do ser-aí, dado o caráter intrín-

7 DESCARTES, Discurso do método, I, p. 5.

8 HEIDEGGER, “A essência da verdade”. In: Marcas do caminho, p. 211.

9 Cf. HEIDEGGER, Ser e tempo, §2.

10 É notória a dificuldade de uma tradução suficiente do termo alemão Dasein, adotado por Heidegger para tratar do ente temático capaz de pôr a pergunta pelo sentido do ser. Desse modo, opto aqui pela já famigerada expressão “ser-aí”, pois considero-a a menos propícia a causar desentendimentos ou incompreensões. 
seco das questões. É dizer: o ser necessita do homem, ao passo que o homem, reciprocamente, só é homem na medida em que compreende ser. Essa analítica existencial foi desenvolvida por Heidegger em Ser e tempo, sua obra seminal. Nela, tem-se que a constituição fundamental do ser-aí é ser-no-mundo. Mundo é um nexo, uma teia de significatividade, um horizonte de sentido. Estando já sempre no mundo, às coisas nos vêm ao encontro de algum modo, isto é, já sempre a compreendemos previamente de um modo ou de outro, e esse compreensão existencial é a condição de possibilidade de toda e qualquer lida com os intes intramundanos.

Contudo, não estamos no mundo como se ele fosse algo em que estívessemos dentro. Em certo sentido, somos nosso mundo. Não há ser-aí que não seja ser-no-mundo. Ser-no-mundo, por sua vez, implica estarmos jogados no mundo, e por conta disso a analítica existencial de Heidegger parte de nossa cotidianidade mediana. O ponto de partida é o próprio senso comum, entendido aqui como aqueles preconceitos que nos constituem, na medida em que o ser-aí é sempre determinado historicamente. A nossa pré-compreensão de ser que define nosso comportamento para com os entes é, em certo sentido, esse senso comum. Desse modo, ele é estrutural, é um existencial do ser-aí. Não é nada pejorativo o fato de sermos decadentes, de estarmos caídos na cotidianidade. Já sempre somos e fomos determinados pelo nosso cotidiano. Segundo Heidegger, entretanto, quando surge a filosofia tem início simultaneamente o domínio do senso comum, da sofística. Isso significa que foi apenas com o surgimento da filosofia, a partir da filosofia, que a cotidianidade pode se manifestar como e enquanto tal. Até então não havia qualquer tipo de dicotomia. Somente com a filosofia e seu surgimento passou a fazer sentido falarmos de um "senso comum" que a ela se opõe. A loucura que se mostra como o critério para determinar a normalidade. Platão nos diz, no Fedro, que "há dois gêneros de loucura: a produzida por doenças humanas e a que por uma revulsão divina nos tira dos hábitos cotidianos" ${ }^{11}$. O que seria essa loucura divina, que sacode nossos pressupostos cotidianos?

No contexto de Ser e tempo, sem dúvida essa loucura seria o que Heidegger deu o nome de angústia. A angústia, segundo Heidegger, é uma disposição de ânimo, mas não uma disposição qualquer: trata-se de uma disposição fundamental do ser-aí. Normalmente, quando ouvimos falar de angústia, temos em mente a ansiedade, a síndrome do

11 PLATÃO, Fedro, 265a. 
pânico, o medo. Tudo isso são humores, patologias, da ordem do ôntico em geral. A angústia, sendo uma disposição e, portanto, de ordem ontológico-existencial, não deve se confundir com nada disso. Não nos angustiamos com coisa alguma, isto é, nenhum ente intramundano é capaz de nos causar angústia. A angústia se dá. Arrebata-nos sem aviso prévio. Gratuitamente, ou seja, sem por quê nem para quê. Quando, e se, a angústia irrompe, sentimo-nos estranhos. Isso significa que a angústia é uma disposição de outra ordem, e por isso Heidegger a caracteriza como fundamental. Imersos na angústia, o mundo não se abre de certo modo: ele se abre como tal; não nos encontramos dispostos de certo modo: a decadência, o fato de estarmos lançados, se apresenta como tal. Precisamente por isso nos sentimos estranhos.

Angustiados, podemos cessar a fuga de nós mesmos. Nós sempre tendemos a fugir para o impessoal, para o cotidiano, nos refugiamos no conforto do hábito, da rotina. Mas, quando estamos estranhos, a familiaridade com as coisas se perde. Com a estranheza, o próprio mundo torna-se estranho a nós. Tudo à nossa volta parece se dissolver. É aí que torna-se possível transcender nosso mundo circundante para termos acesso ao mundo enquanto tal. O mundo circundante é nosso mundo imediato, nossa facticidade, a cotidianidade mediana onde se desenrola nossa vida. Arrebatados pela angústia, o mundo como tal mostra-se como sendo nada, pois não é coisa alguma, ente algum. A reboque, e pelo mesmo motivo, fica claro que nosso ser-aí é também nada. Se somos nada em meio ao nada, impõe-se a questão aterradora: o que é o nada?

No nosso interrogar já pressupomos antecipadamente o nada como algo que “é” de tal e tal modo - como um ente. É dele precisamente, porém, que o nada se distingue pura e simplesmente. (...) Se for assim, também toda resposta a esta questão é, desde o início, impossível. Pois ela se desenvolve necessariamente sob esta forma: o nada "é" isto ou aquilo" ${ }^{12}$

Questionar o nada contraria toda a lógica que baseia nossos raciocínios, pois a questão obriga o nada a objetificar-se, o que é um evidente contrassenso, já que o nada nada é. Mas será que quando Heidegger tematiza o nada, ele o faz dentro do escopo da lógica? Que estamos chamando aqui de lógica? “Lógica”, nesse contexto específi$\mathrm{co}^{13}$, é precisamente o senso comum, no sentido da compreensão imediata e mediana,

12 HEIDEGGER, “O que é metafísica”. In: Marcas do caminho, p. 117.

13 Isto é, não se trata aqui da Lógica entendida como uma área do saber filosófico. 
impessoal, para com as coisas. Partimos de nossas pressuposições, que por definição são inquestionadas, impensadas, e as tomamos como o critério e a medida da interpretação e compreensão do real. Quando partimos tendo como medida nossas pré-concepções, o interpretado tem que adequar-se à elas, e, consequentemente, o fim será uma equalização, pois o que há de novo não se encaixa e deve sofrer a moléstia da correção forçada. Partindo do senso comum, a hermenêutica nada mais é que um "Leito de Procusto".

A "lógica", entendida desse modo, tem um caráter excludente essencial"14. Ela opera com a díade, com pares opostos, onde a posição de um dos "lados" exclui a possibilidade de ser do outro. Se é bom, não é mau, e vice versa, e assim por diante: se é frio, não é quente; se é belo, não é feio etc. Justamente por ser algo universal, comum, ela estabelece o padrão da obviedade. Obviedade aqui diz a lassidão, o sono, o marasmo, a letargia, a preguiça, a fuga. O que é óbvio nunca é questionado, pois já é sabido. O óbvio traz consigo essa mecanização, esse automatismo, essa rotina, esse hábito. Entretanto, no que diz respeito a esta discussão, Platão nos dá a pensar. No Banquete, Sócrates narra em seu discurso sobre Eros a doutrina que havia ouvido de Diotima de Mantinéia. Diotima teria demonstrado a Sócrates, dialeticamente, que Eros não podia ser nem belo nem bom ${ }^{15}$. Ao que Sócrates rebate, escandalizado:

Como assim, Diotima! Nesse caso, Eros é feio e mau?

E ela: Não blasfemes! Pensas, porventura, que o que não é belo terá de ser necessariamente feio?

- Sem dúvida.

E quem não for sábio, será ignorante? Não percebeste que há algo intermediário entre a sabedoria e a ignorância?

- Que poderá ser?

A opinião verdadeira de alguma coisa, sem que se possa justificá-la. Como bem sabes, continuou, nem é conhecimento - pois como poderá haver conhecimento do que não se pode demonstrar? - nem ignorância, visto não poder ser ignorância o que atinge, de algum modo, o real. A opinião verdadeira é qualquer coisa desse tipo, entre a compreensão e a ignorância.

14 Como ilustração desse binarismo excludente da "lógica" tal como entendida aqui, Cf. HEIDEGGER, “Carta sobre o humanismo". In: Marcas do caminho, pp. 359-360.

15 Cf. PLATÃO, Banquete, 199c ss. 
- Tens razão, lhe disse.

Não obrigues, por conseguinte, a ser feio o que não é belo, nem a ser ruim o que não for bom. É o que se dá com Eros: uma vez que tu mesmo admitiste não ser ele nem belo nem bom, não te ponhas a imaginar que ele seja feio e mau, porém algo, arrematou, entre esses dois extremos ${ }^{16}$.

Sócrates iniciou a conversa partindo do senso comum, do binarismo excludente da "lógica”. Diotima o estarrece com a introdução de um elemento essencial: o entre. Diante da lógica do ou-ou, Diotima afirma o hífen. Esta capacidade de enxergar o meio termo, pensando agora com Aristóteles, não é justamente o que caracteriza o sábio, o virtuoso? No entanto, nos dias de hoje, onde a tecnociência é a norma e a medida e se espraia como método em todos os âmbitos da vida, o "meio termo que define a virtude" tornou-se cálculo, e o grande exemplo disso é a medicina, que tem tido, a cada vez mais, a pretensão de ser uma ciência exata, uniformizando as prescrições para todos os pacientes. E, na sequência do trecho do Banquete, de Platão, citado acima, Sócrates é conduzido por Diotima, dialeticamente, a afirmar que Eros, ao contrário do que vinha sendo dito ao longo de todo o Banquete, não é um deus. Sócrates, ainda imerso na atmosfera do senso comum, ainda incapaz de sair da dicotomia do ou-ou, questiona atônito se Eros, seria, portanto, um mortal. Mais uma vez Diotima o repreende: Eros é algo intermediário, não ser um deus não significa que seja necessariamente mortal; Eros é precisamente o entre deuses e mortais: um $\delta \alpha i \mu \omega v^{17}$.

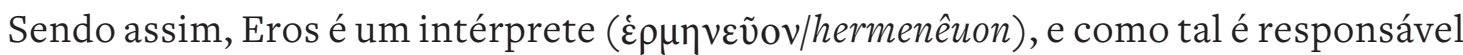
pela comunicação entre deuses e mortais, uma ponte entre os comandos divinos e os sacrifícios humanos. Quanto à sua proveniência, Eros é, segundo Diotima, filho de Penia, a pobreza, com Poro, o recurso. Por conta disso, por ter herdado aspectos tanto da mãe quanto do pai, a caracterização que Diotima dá a Eros é o que, em nosso contexto, é valiosíssimo. Ela diz:

Para começar, é sempre pobre e está longe de ser delicado e belo, conforme crê o vulgo. Ao revés disso: é áspero, esquálido e sem calçado nem domicílio certo; só dorme sem agasalho e ao ar livre, no chão duro, pelas portas das casas e nas estradas. Tendo herdado a natureza da mãe, é companheiro eterno da indigência. Por outro lado, como filho de tal pai, vive a excogitar ardis para apanhar

16 PLATÃO, Banquete, 201d-202b.

17 PLATÃO, Banquete, 202e. 
tudo o que é belo e bom; é bravo, audaz, expedito, excelente caçador de homens, fértil em ardis, amigo da sabedoria, sagacíssimo, filósofo o tempo todo, feiticeiro temível, mágico e sofista ${ }^{18}$.

Sendo ao mesmo tempo filho da pobreza e da riqueza, da indigência e do recurso, a natureza de Eros é paradoxal. Chama particularmente a atenção o fato de ele ser, ao mesmo tempo, filósofo e sofista, apresentando aspectos de ambos concomitantemente, tais como "amigo da sabedoria”, que em grego diz, na verdade, $\varphi \rho \circ v \eta ́ \sigma \varepsilon \omega \varsigma$

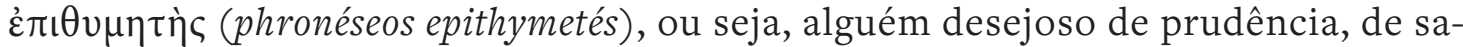
bedoria prática, e "sagacíssimo", тó derivado de Poro, recurso -, aspectos que poderíamos chamar de apropriados ao fi-

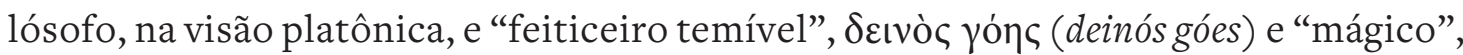

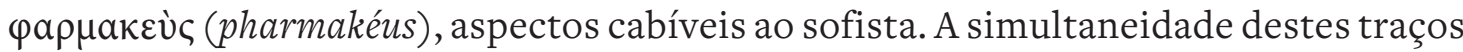
em sua essência é bastante estranha. Como tal deslize pode ter escapado a Platão? Ou se é filósofo ou se é sofista, não? Ao ouvir esta pergunta, Diotima sorri.

Há algo nessa descrição que passa desapercebido, mas que talvez seja vital: que Eros

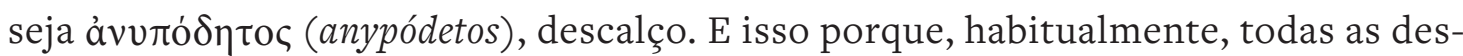
crições de Sócrates chamam a atenção para o fato de ele perambular descalço por Atenas. Ademais, Sócrates, na Apologia, diz que persistiu na vida filosófica por ser esta uma missão divina, e que isso fez com que ele ficasse pobre, tal como Eros. Eros é ảoıkoৎ (áoikos), sem lar, e embora a analogia aqui pareça vacilar, pois Sócrates nunca saiu de Atenas, tendo pois, um lar, vale lembrar o quão recorrentemente ele era cha-

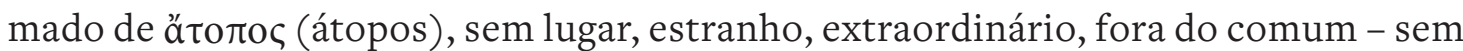
contar a famosa frase que Plutarco atribuiu a Sócrates, de que ele não era ateniense, mas sim um cidadão do mundo. Que Sócrates não era belo, tal como Eros, é também notório. Que ele era um “excelente caçador de homens” é também atestado em vários diálogos, como o Protágoras, e sua capacidade de sedução é referida no Mênon e no próprio Banquete, no discurso de Alcibíades. Por sinal, no Banquete, onde todos os personagens devem fazer um elogio a Eros, Alcibíades, ébrio, faz um discurso a Sócrates. Por fim, que Sócrates tenha sido filósofo não resta dúvidas, mas recorrentemente ele era confundido com os sofistas, ou chamado de sofista descaradamente até, como na comédia As Nuvens, de Aristófanes. As coincidências são tantas que não

18 PLATÃO, Banquete, 203c-e. 
dá para se negar como algo acidental: a personagem Sócrates, de Platão, enquanto paradigma do filósofo ideal, é Eros. Isso significa que o filósofo, em sua perfeição, precisa ser pobre, estranho e sofista, não há “pureza”, pois ele é justamente o entre. Heidegger: "O homem é como uma ponte constante no entre, como o qual o acontecimento apropriador atribui a indigência dos deuses para a guarda do homem, na medida em que ele assume a responsabilidade pelo homem e o entrega ao ser-aí"19. O ser-aí é o entre o divino e o humano, mas não como se ambos, o divino e o humano, fossem coisas dadas, margens definidas ou algo do tipo. O ser-aí é ambos, simultaneamente, sem ser nenhum, especificamente. Ele é o que dá sentido a ambos, é o que há de con-creto, isto é, o que con-cresce, faz crescer junto. O ser-aí, enquanto o entre, é uma dobra entre o ôntico e o ontológico. Ele transcende o ôntico, mas não no sentido

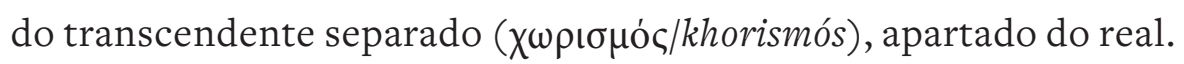

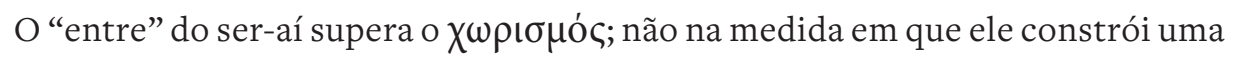
ponte entre o seer (a entidade) e o ente como margens por assim dizer presentes, mas na medida em que ele transforma o seer e o ente ao mesmo tempo em sua coetanidade ${ }^{20}$.

Daí o ser-aí enquanto entre, enquanto Eros, $\delta \alpha i \mu \omega v$, ser ao mesmo tempo filósofo e sofista: Heidegger havia associado o senso comum com a sofística, e, portanto, somos sempre já "sofistas", na medida em que nos ocupamos das coisas mundanas. Sofística aqui diz a nossa decadência estrutural na cotidianidade. O perigo é que a sofística, o senso comum, a lógica, tem sempre, e hoje mais do que nunca, pretensão de assenhoramento, eliminando a "filosofia” do quadro de possibilidades. Restaria apenas o falatório, enquanto aquele fenômeno estrutural da cotidianidade que significa a “possibilidade de compreender tudo sem se ter apropriado previamente da coisa"21, ou seja, aquela retórica, alardeada pelos antigos sofistas, orgulhosa de ser capaz de falar sobre tudo, inclusive com maior poder de convencimento do que quem realmente possui algum saber. Haver o falatório não é problema, tendo em vista que ele, como dito, é estrutural, e como tal “inescapável”. O problema é ele se passar por algo que não é, a saber, pensamento, saber, no sentido forte. Aristóteles já dizia, e sem dúvida Platão assinaria embaixo, que os sofistas, exteriormente, têm o mesmo aspecto do

19 HEIDEGGER, Contribuições à filosofia, \$271, p. 472.

20 Idem, ibidem, §5, p. 18.

21 HEIDEGGER, Ser e tempo, \$35, p. 229. 
filósofo, a diferença é que o sofista teria uma sabedoria apenas aparente ${ }^{22}$. Sofista e filósofo são tão parecidos que, no diálogo Sofista, o Estrangeiro de Eleia, buscando dialeticamente com a ajuda de Teeteto a definição da essência do sofista, acaba encontrando, antes o filósofo: "Por Zeus, não estaremos, sem o sabermos, dirigindo-nos para a ciência dos homens livres e correndo o risco, nós que procuramos o sofista, de haver, antes de encontrá-lo, descoberto o filósofo?”23.

\section{REFERÊNCIAS BIBLIOGRÁFICAS}

ARISTÓTELES. Metafísica. Trad. Marcelo Perine. São Paulo: Loyola, 2002.

BORNHEIM, G. Introdução ao filosofar: o pensamento filosófico em bases existenciais. $11^{\mathrm{a}}$ ed. São Paulo: Globo, 2003.

DESCARTES, R. Discurso do método. Trad. Maria E. de Almeida Prado Galvão. São Paulo: Martins Fontes, 2011.

DIÓGENES LAÉRCIO. Vidas e doutrinas dos filósofos ilustres. Trad. Mário da Gama. $2^{\mathrm{a}}$ ed. Brasília: UNB, 2008.

HEIDEGGER, M. Contribuições à filosofia: do acontecimento apropriador. Trad. Marco Antônio Casanova. Rio de Janeiro: Via Verita, 2015.

Marcas do caminho. Trad. E. P. Giachini e E. Stein. Petrópolis: Vozes, 2008.

. Ser e tempo. Trad. Márcia Sá Cavalcante Schuback. 6ª ed. Petrópolis: Vozes, 2006.

PLATÃO. Banquete. Trad. Carlos Alberto Nunes. Belém: UFPA, 2011.

Diálogos. Trad. Carlos Alberto Nunes. Belém: UFPA, 1985.

Fedro. Trad. Carlos Alberto Nunes. Belém: UFPA, 2011.

Teeteto. Trad. Adriana Manuela Nogueira; Marcelo Boeri. $3^{\text {a }}$ ed. Lisboa: Calouste Gulbenkian, 2010.

22 Cf. ARISTÓTELES, Metafísica, Г $21004 \mathrm{~b}$.

23 PLATÃO, Sofista, $253 \mathrm{c}$. 